\title{
Perbandingan Akurasi Algoritma C4.5 dan CART dalam Memprediksi Kategori Indeks Prestasi Mahasiswa
}

\author{
Dea Alverina*), Antonius Rachmat Chrismanto, R. Gunawan Santosa \\ Program Studi Informatika, Fakultas Teknologi Informasi, Universitas Kristen Duta Wacana \\ Jalan Doktor Wahidin Sudirohusodo No. 5-25, Kotabaru, Gondokusuman, Yogyakarta, Indonesia
}

Cara sitasi: D. Alverina, A. R. Chrismanto, and R. G. Santosa, "Perbandingan Akurasi Algoritma C4.5 dan CART dalam Memprediksi Kategori Indeks Prestasi Mahasiswa," Jurnal Teknologi dan Sistem Komputer, vol. 6, no. 2, Apr. 2018. doi: 10.14710/jtsiskom.6.2.2018.76-83, [Online].

\begin{abstract}
This research compared the accuracy of prediction of Grade Point Average (GPA) of the first semester students using $C 4.5$ and $C A R T$ algorithms in Faculty of Information Technology (FTI), Universitas Kristen Duta Wacana (UKDW). This research also explored various parameters such as numeric attribute categorization, data balance, GPA categories number, and different attributes availability due to the difference of data availability between Achievement Admission (AA) and Regular Admission (RA). The training data used to create decision tree were FTI students, 2008-2015 batch, while the testing data were FTI students, 2016 batch. The accuracy of prediction was measured by using crosstab table. In AA, the accuracy of both algorithms can be achieved about $86.86 \%$. Meanwhile, in $R A$ the accuracy of $C 4.5$ is about $61.54 \%$ and CART is about $63.16 \%$. From these accuracy result, both algorithms are better to predict $A A$ rather than $R A$.
\end{abstract}

Keywords - data mining accuracy; student grade prediction; prediction algorithms comparison

Abstrak - Penelitian ini membandingkan akurasi prediksi kategori Indeks Prestasi (IP) semester pertama mahasiswa Fakultas Teknologi Informasi (FTI) Universitas Kristen Duta Wacana (UKDW) menggunakan algoritma C4.5 dan CART. Penelitian ini juga mengeksplorasi berbagai parameter seperti kategorisasi atribut numerik, keseimbangan data, jumlah kategori IP, dan ketersediaan atribut yang berbeda karena perbedaan ketersediaan data antara jalur prestasi dan jalur non-prestasi. Data mahasiswa FTI tahun 2008-2015 digunakan sebagai data latih sedangkan data uji menggunakan data tahun 2016. Akurasi kedua algoritma dalam memprediksi tersebut diukur dengan menggunakan tabel crosstab. Pada jalur prestasi, akurasi kedua algoritma mampu mencapai 86,86\%. Pada jalur non-prestasi, akurasi algoritma C4.5 sebesar 61,54\% dan algoritma CART sebesar 63,16\%. Dilihat dari segi akurasinya, algoritma C4.5 dan CART lebih baik digunakan untuk

*) Penulis korespondensi (Dea Alverina)

Email: dea.alverina@ti.ukdw.ac.id memprediksi jalur prestasi daripada jalur nonprestasi.

Kata Kunci - akurasi data mining; prediksi prestasi mahasiswa; perbandingan algoritma prediksi

\section{Pendahuluan}

Performa akademis mahasiswa baru di semester pertama yang di bawah rata-rata dapat menimbulkan berbagai masalah, di antaranya adalah efek berantai performa rendah untuk semester-semester berikutnya. Terdapat beberapa faktor eksternal dan internal yang mempengaruhi tinggi rendahnya prestasi akademis mahasiswa baru. Faktor-faktor eksternal meliputi kategori asal SMA (pulau Jawa atau luar pulau Jawa), kategori SMA (SMA atau SMK), dan status SMA (Negeri atau Swasta). Faktor internal meliputi kemampuan spasial, kemampuan verbal, kemampuan numerik dan kemampuan analogi [1]. Lebih lanjut, Indriana dkk. [2] menyatakan bahwa ada perbedaan prestasi akademik mahasiswa yang bekerja dan yang tidak bekerja saat menempuh pendidikan.

Data-data dari faktor tersebut dapat diperoleh pada saat pendaftaran mahasiswa baru, namun tidak semua data dapat diperoleh. Hal tersebut disebabkan oleh adanya dua jalur penerimaan mahasiswa baru, yaitu jalur prestasi dan jalur non-prestasi. Penerimaan mahasiswa baru yang melalui jalur prestasi akan dilihat dari faktor eksternal dan yang melalui jalur non-prestasi akan dilihat dari faktor eksternal maupun faktor internal. Mahasiswa baru yang mendaftar melalui jalur prestasi dan jalur non-prestasi akan diuji kemampuan bahasa Inggrisnya yang dipetakan menjadi beberapa level, yaitu level 1, level 2, level 3, atau level ESP.

Prediksi indeks prestasi (IP) mahasiswa semester satu perlu dilakukan secara dini untuk menanggulangi masalah-masalah yang mungkin akan ditimbulkan oleh mahasiswa di kemudian hari dan melakukan pembimbingan. Prediksi mahasiswa berprestasi telah dilakukan oleh Untari [3] menggunakan algoritma C4.5, sedangkan Kamagi dan Hansun [4] menggunakan algoritma tersebut untuk memprediksi tingkat kelulusan mahasiswa. Metode dan algoritma lain yang digunakan untuk prediksi adalah metode regresi logistik untuk 
Tabel 1. Jumlah data mahasiswa Fakultas Teknologi Informasi tahun 2008-2015

\begin{tabular}{cccc}
\hline Tahun & Jalur Prestasi & Jalur Non-Prestasi & Total \\
\hline 2008 & 63 & 305 & 368 \\
2009 & 11 & 249 & 260 \\
2010 & 55 & 209 & 264 \\
2011 & 144 & 107 & 251 \\
2012 & 125 & 119 & 244 \\
2013 & 125 & 80 & 205 \\
2014 & 90 & 81 & 171 \\
2015 & 193 & 61 & 254 \\
Total & $\mathbf{8 0 6}$ & $\mathbf{1 2 1 1}$ & $\mathbf{2 0 1 7}$ \\
\hline
\end{tabular}

prediksi IP mahasiswa baru dari jalur prestasi [1] dan non-prestasi [5], algoritma K-Nearest Neighbor dan Naive Bayes untuk prediksi kategori IP mahasiswa [6] serta metode CART untuk klasifikasi ketepatan masa studi mahasiswa [7]. Perbandingan akurasi prediksi antar algoritma untuk klasifikasi dan analisis data nilai mahasiswa telah dilakukan, salah satunya adalah antara algoritma C4.5 dan CART [8], [9].

Prediksi dalam [3] dan [4] menggunakan data nonnumerik dan kategori output yang hanya memiliki 1 macam kategori saja untuk mahasiswa aktif. Selain itu, ditemukan perbedaan dalam [8] yang menyatakan bahwa algoritma C4.5 cocok digunakan untuk klasifikasi data non-numerik daripada algoritma CART yang cocok untuk data numerik dan dalam [9] yang menyatakan bahwa performa CART lebih baik daripada C4.5 dimana data yang digunakan adalah data nonnumerik. Penelitian ini bertujuan untuk menerapkan algoritma C4.5 dan CART untuk prediksi kategori IP mahasiswa baru semester satu dengan mengeksplorasi berbagai parameter, yaitu kategorisasi angka numerik, keseimbangan data, jumlah kategori IP dan ketersediaan atribut yang berbeda antara mahasiswa dari jalur prestasi dan jalur non-prestasi. Penelitian ini juga menganalisis dan membandingkan akurasi algoritma C4.5 dan CART untuk menentukan algoritma yang lebih baik dalam memprediksi kategori IP mahasiswa baru semester satu.

\section{Metode Penelitian}

\section{A. Pengumpulan Data}

Data yang digunakan pada penelitian ini diambil dari penelitian yang telah dilakukan oleh Santosa \& Rachmat [1]. Tabel 1 menunjukkan tabel jumlah data berdasarkan jumlah mahasiswa FTI dari tahun 2008 sampai dengan tahun 2015, yaitu 2.017 data. Data mahasiswa tersebut akan dikategorikan berdasarkan jalur penerimaan, yaitu jalur prestasi dan jalur nonprestasi. Jalur prestasi memiliki atribut kategori (SMU atau SMK), status (negeri atau swasta), lokasi (Jawa atau luar Jawa), dan level (1, 2, 3, atau ESP). Jalur nonprestasi memiliki atribut kategori (SMU atau SMK), status (negeri atau swasta), lokasi (Jawa atau luar Jawa), level (1, 2, 3, atau ESP), nilai numerik, nilai verbal, nilai spasial dan nilai analogi.

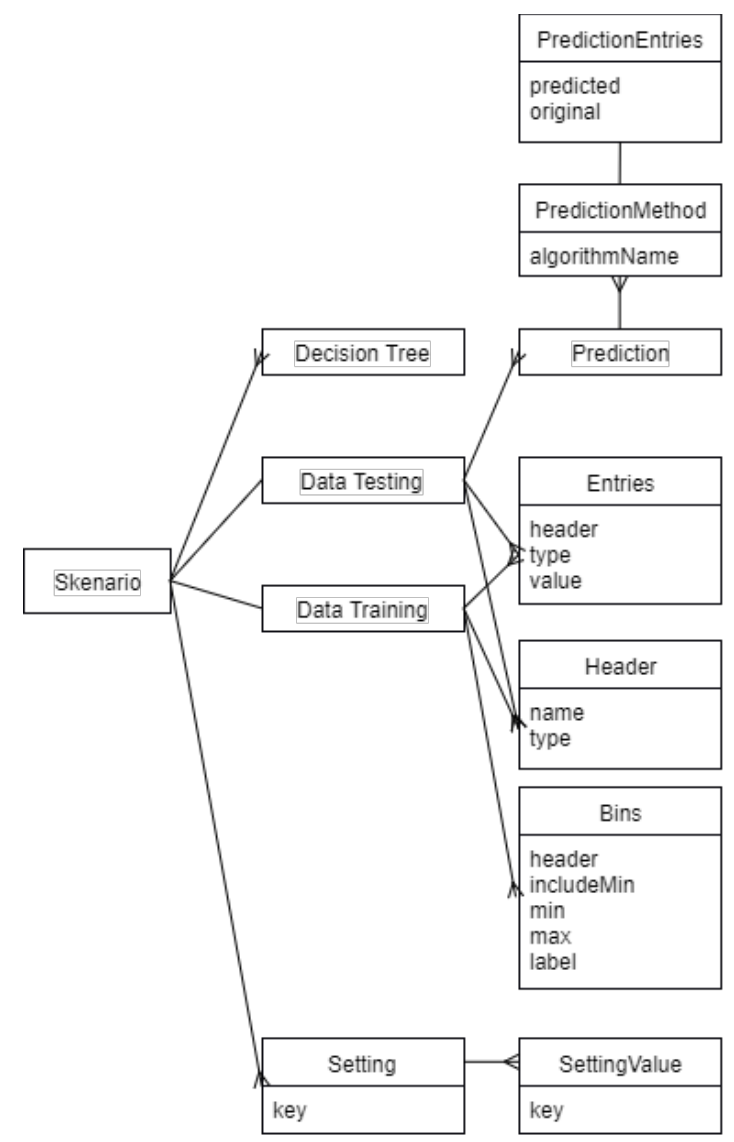

Gambar 1. Rancangan struktur basis data

\section{B. Perancangan Sistem}

Jalannya program diawali dengan menampilkan kumpulan Skenario dengan struktur objek ditunjukkan pada Gambar 1. Sebuah Skenario menyimpan data latih (training), data uji (testing), settings, dan decision tree. Data latih memiliki entries, header, dan bins. Data uji memiliki entries, header, dan prediction (hasil prediksi). Settings digunakan untuk menyimpan berbagai parameter, di antaranya ip_kategori dan atribut yang diinferensi. Data decision tree yang disimpan pada skenario dalam bentuk tree, memanfaatkan fitur NoSQL. Basis data yang digunakan pada program prediksi kategori IP adalah NoSQL yang dapat menyimpan data yang memiliki struktur dinamis [10].

Input data Skenario berupa data pelatihan dan jumlah kategori IP. Sebelum dilakukan klasifikasi, dilakukan preprocessing, meliputi cleaning untuk membersihkan data yang tidak lengkap dan binning terhadap atribut IP dan atribut numerik. Binning dilakukan pada atribut numerik non-output dengan jumlah bin sebesar 5, hanya jika pengguna memilih untuk melakukan binning pada atribut numerik tersebut. Pada atribut pasti, binning dilakukan dengan jumlah bin sebesar jumlah kategori IP.

\section{Proses Pelatihan}

Data latih yang digunakan adalah data mahasiswa angkatan 2008-2014. Sebelum melakukan pelatihan data latih, dilakukan tahap preprocessing, yaitu meliputi 
transformasi data, data cleaning serta binning dan threshold. Transformasi data memodifikasi atributatribut kosong dari atribut yang tersedia pada data, misalnya dari atribut Sekolah "SMA Negeri 3 Yogyakarta", dapat disimpulkan bahwa statSMU adalah Negeri, katSMU adalah SMU, dan lokSMU adalah Jawa. Data Cleaning digunakan untuk membersihkan data dari entry yang memiliki missing value yang tidak bisa dikembalikan pada tahap transformasi data.

Binning dan threshold dilakukan pada skenario yang menggunakan data mahasiswa non-prestasi. Pada data mahasiswa jalur prestasi, tidak ada atribut numerik sehingga tidak dilakukan binning pada prediksi jalur prestasi. Threshold digunakan untuk membuat child node dari atribut numerik, split terbaik akan dihitung dengan mengintegrasi threshold di antara unique value dari atribut tersebut. Untuk mengetahui nilai dari suatu split, digunakan rumus Information Gain untuk algoritma C4.5 atau Gini Impurity untuk algoritma CART seperti pada split atribut non-numerik, namun dengan dua child, yaitu lebih besar dari threshold dan lebih kecil dari threshold.

Kategori atribut-atribut numerik (num, ver, ana, dan spa) yang dinyatakan ke dalam 5 kategori ditunjukkan dalam Tabel 2. Binning juga dilakukan pada setiap skenario untuk atribut ips1. Tabel 3 menunjukkan 2 kategori IP, yaitu A yang berarti IP tersebut rendah dan $\mathrm{B}$ yang berarti IP tersebut tinggi. Tabel 4 menunjukkan 3 kategori IP, yaitu A yang berarti IP tersebut rendah, B yang berarti IP tersebut sedang dan $\mathrm{C}$ yang berarti IP tersebut tinggi. Tabel 5 menunjukkan tabel kategori IP sebanyak 4 kategori, yaitu A yang berarti IP tersebut sangat rendah, B yang berarti IP tersebut rendah, C yang berarti IP tersebut tinggi dan D yang berarti IP tersebut sangat tinggi. Tabel 6 menunjukkan tabel kategori IP sebanyak 5 kategori, yaitu A yang berarti IP tersebut sangat rendah, B yang berarti IP tersebut rendah, C yang berarti IP tersebut sedang, D yang berarti IP tersebut tinggi dan E yang berarti IP tersebut sangat tinggi.

Setelah proses preprocessing, program membuat decision tree berdasarkan data latih tersebut. Decision tree tersebut digunakan untuk melakukan pengujian terhadap data uji. Data uji harus memiliki atribut-atribut yang sama dengan data latih.

\section{Proses Pengujian}

Data uji yang akan digunakan adalah data mahasiswa angkatan 2015. Tabel 7 menunjukkan 24 skenario pengujian dalam penelitian. Skenario pengujian dibagi berdasarkan jalur penerimaan mahasiswa, yaitu jalur prestasi sebanyak 8 skenario dan jalur non-prestasi sebanyak 16 skenario. Skenario jalur prestasi dibagi berdasarkan keseimbangan data, yaitu jalur prestasi data seimbang sebanyak 4 skenario dan jalur prestasi data tidak seimbang sebanyak 4 skenario.

Skenario jalur non-prestasi dibagi berdasarkan keseimbangan data dan kategorisasi atribut numerik. Pembagian tersebut adalah data seimbang dengan atribut numerik yang dilakukan threshold sebanyak 4 skenario, data seimbang dengan atribut numerik yang dilakukan binning sebanyak 4 skenario, data tidak
Tabel 2. Kategori atribut numerik sebanyak 5 kategori

\begin{tabular}{ccl}
\hline Nilai & Kategori & \multicolumn{1}{c}{ Keterangan } \\
\hline $0-40$ & A & Sangat Rendah \\
$41-80$ & B & Rendah \\
$81-120$ & C & Sedang \\
$121-160$ & D & Tinggi \\
$161-200$ & E & Sangat Tinggi \\
\hline
\end{tabular}

Tabel 3. Kategori indeks prestasi sebanyak 2 kategori

\begin{tabular}{ccl}
\hline Indeks Prestasi & Kategori IP & Keterangan \\
\hline $0-2$ & A & Rendah \\
$2,1-4$ & B & Tinggi \\
\hline
\end{tabular}

Tabel 4. Kategori indeks prestasi sebanyak 3 kategori

\begin{tabular}{ccl}
\hline Indeks Prestasi & Kategori IP & Keterangan \\
\hline $0-1.33$ & $\mathrm{~A}$ & Rendah \\
$1.34-2.67$ & $\mathrm{~B}$ & Sedang \\
$2.68-4$ & $\mathrm{C}$ & Tinggi \\
\hline
\end{tabular}

Tabel 5. Kategori indeks prestasi sebanyak 4 kategori

\begin{tabular}{ccl} 
Indeks Prestasi & Kategori IP & \multicolumn{1}{c}{ Keterangan } \\
\hline $0-1$ & A & Sangat Rendah \\
$1.1-2$ & B & Rendah \\
$2.1-3$ & C & Tinggi \\
$3.1-4$ & D & Sangat Tinggi \\
\hline
\end{tabular}

Tabel 6. Kategori indeks prestasi sebanyak 5 kategori

\begin{tabular}{ccl}
\hline Indeks Prestasi & Kategori IP & \multicolumn{1}{c}{ Keterangan } \\
\hline $0-0.8$ & A & Sangat Rendah \\
$0.9-1.6$ & B & Rendah \\
$1.7-2.4$ & C & Sedang \\
$2.5-3.2$ & D & Tinggi \\
$3.3-4$ & E & Sangat Tinggi \\
\hline
\end{tabular}

Tabel 7. Rangkuman pengujian

\begin{tabular}{|c|c|c|c|c|c|c|}
\hline \multirow[b]{2}{*}{$\begin{array}{c}\text { Nama } \\
\text { Skenario }\end{array}$} & \multirow[b]{2}{*}{ Binning } & \multicolumn{2}{|c|}{ Metode } & \multicolumn{2}{|c|}{ Data Latih } & \multirow[b]{2}{*}{$\begin{array}{c}\text { Kategori } \\
\text { IP }\end{array}$} \\
\hline & & C4.5 & CART & Seimbang & $\begin{array}{c}\text { Tidak } \\
\text { Seimbang }\end{array}$ & \\
\hline Skenario 1 & Tidak & $\mathrm{V}$ & $\mathrm{V}$ & $\mathrm{V}$ & & 2 \\
\hline Skenario 2 & Tidak & V & V & & $\mathrm{V}$ & 2 \\
\hline Skenario 3 & Tidak & V & V & V & & 3 \\
\hline Skenario 4 & Tidak & V & V & & V & 3 \\
\hline Skenario 5 & Tidak & V & V & V & & 4 \\
\hline Skenario 6 & Tidak & $\mathrm{V}$ & V & & $\mathrm{V}$ & 4 \\
\hline Skenario 7 & Tidak & $\mathrm{V}$ & $\mathrm{V}$ & V & & 5 \\
\hline Skenario 8 & Tidak & V & V & & V & 5 \\
\hline Skenario 9 & Tidak & V & V & $\mathrm{V}$ & & 2 \\
\hline Skenario 10 & Tidak & V & $\mathrm{V}$ & & V & 2 \\
\hline Skenario 11 & Tidak & V & V & V & & 3 \\
\hline Skenario 12 & Tidak & V & V & & V & 3 \\
\hline Skenario 13 & Tidak & V & $\mathrm{V}$ & V & & 4 \\
\hline Skenario 14 & Tidak & V & V & & V & 4 \\
\hline Skenario 15 & Tidak & V & V & V & & 5 \\
\hline Skenario 16 & Tidak & V & V & & V & 5 \\
\hline Skenario 17 & Ya & V & $\mathrm{V}$ & V & & 2 \\
\hline Skenario 18 & $\mathrm{Ya}$ & V & V & & V & 2 \\
\hline Skenario 19 & $\mathrm{Ya}$ & V & $\mathrm{V}$ & V & & 3 \\
\hline Skenario 20 & $\mathrm{Ya}$ & V & $\mathrm{V}$ & & V & 3 \\
\hline Skenario 21 & $\mathrm{Ya}$ & V & $\mathrm{V}$ & $\mathrm{V}$ & & 4 \\
\hline Skenrio 22 & $\mathrm{Ya}$ & V & V & & V & 4 \\
\hline Skenario 23 & $\mathrm{Ya}$ & V & V & V & & 5 \\
\hline Skenario 24 & $\mathrm{Ya}$ & V & $\mathrm{V}$ & & V & 5 \\
\hline
\end{tabular}


Tabel 8. Tabel tabulasi silang

\begin{tabular}{cccc}
\hline & $\mathbf{B}_{1}$ & $\mathbf{B}_{2}$ & Total \\
\hline $\mathbf{A}_{1}$ & $\mathrm{P}_{11}$ & $\mathrm{P}_{12}$ & $\mathrm{P}_{1+}$ \\
$\mathbf{A}_{\mathbf{2}}$ & $\mathrm{P}_{21}$ & $\mathrm{P}_{22}$ & $\mathrm{P}_{2+}$ \\
Total & $\mathrm{P}_{+1}$ & $\mathrm{P}_{+2}$ & $\mathrm{n}$ \\
\hline Keterangan: & & \\
A dan B $=$ Variabel & $\mathrm{P}_{1+}=\mathrm{P}_{11}+\mathrm{P}_{12}$ \\
$\mathrm{P}_{+1}=\mathrm{P}_{11}+\mathrm{P}_{21}$ & $\mathrm{P}_{2+}=\mathrm{P}_{21}+\mathrm{P}_{22}$ \\
$\mathrm{P}_{+2}=\mathrm{P}_{12}+\mathrm{P}_{22}$ & $\mathrm{n}=\mathrm{P}_{+1}+\mathrm{P}_{+2}$ atau $\mathrm{P}_{1+}+\mathrm{P}_{2+}$
\end{tabular}

seimbang dengan atribut numerik yang dilakukan threshold sebanyak 4 skenario dan data tidak seimbang dengan atribut numerik dilakukan binning sebanyak 4 kategori. Sebelum dilakukan pengujian, dilakukan proses preprocessing terhadap data uji dengan langkah yang sama dengan proses preprocessing data latih.

\section{E. Pengukuran Akurasi Algoritma}

Metode yang digunakan untuk mengukur keakuratan hasil prediksi adalah tabel tabulasi silang (crosstab). Tabulasi silang digunakan untuk menghitung akurasi dari algoritma C4.5 dan algoritma CART, seperti ditunjukkan dalam Tabel 8. Nilai akurasi hasil prediksi dinyatakan dalam Persamaan 1.

$$
\operatorname{Kecocokan}(\%)=\frac{P_{11}+P_{22}}{n}
$$

\section{Hasil dan Pembahasan}

Hasil proses preprocessing dari semua data latih dan data uji pada tiap skenario ditunjukkan dalam Tabel 9. Skenario nomor ganjil merupakan skenario dengan data seimbang. Data seimbang cenderung berjumlah kecil karena terdapat selisih yang besar antara satu kategori indeks prestasi dengan kategori indeks prestasi lainnya.

Rangkuman hasil pengujian skenario 1 sampai skenario 24 dan parameternya ditunjukkan dalam Tabel 10. Akurasi rata-rata untuk algoritma $\mathrm{C} 4.5$ adalah $41,48 \%$ dan algoritma CART adalah $42,65 \%$. Dari tabel 10, diketahui bahwa kedua algoritma, C4.5 dan CART, dapat mencapai akurasi sebesar $86,86 \%$ (skenario 2). Akurasi tersebut dihasilkan dari data jalur prestasi yang tidak seimbang dengan kategori indeks prestasi sebanyak 2 kategori. Untuk data jalur non-prestasi, akurasi terbaik untuk algoritma C4.5 sebesar $61,54 \%$ (skenario 18) dimana data latih tidak seimbang dan atribut numerik dikategorikan, sedangkan akurasi terbaik untuk algoritma CART sebesar 63,16\% (skenario 10) dimana data latih tidak seimbang dan atribut numerik tidak dikategorikan.

Rangkuman hasil pengujian untuk kasus penerimaan mahasiswa melalui jalur prestasi tanpa binning ditunjukkan dalam Tabel 11. Akurasi rata-rata algoritma $\mathrm{C} 4.5$ adalah $52,84 \%$ dan algoritma CART adalah 53,52\%. Rangkuman hasil pengujian untuk kasus penerimaan mahasiswa melalui jalur non-prestasi ditunjukkan dalam Tabel 12. Akurasi rata-rata untuk algoritma C4.5 adalah 35,35\% dan algoritma CART adalah $37,38 \%$.
Tabel 9. Total data latih dan data uji sebelum dan setelah preprocessing

\begin{tabular}{ccccc} 
Nama & \multicolumn{2}{c}{ Total Data Latih } & \multicolumn{2}{c}{ Total Data Uji } \\
\cline { 2 - 5 } Skenario & Sebelum & Setelah & Sebelum & Setelah \\
\hline Skenario 1 & 158 & 158 & 193 & 137 \\
Skenario 2 & 613 & 554 & 193 & 137 \\
Skenario 3 & 120 & 120 & 193 & 137 \\
Skenario 4 & 613 & 554 & 193 & 137 \\
Skenario 5 & 128 & 128 & 193 & 137 \\
Skenario 6 & 613 & 554 & 193 & 137 \\
Skenario 7 & 125 & 125 & 193 & 137 \\
Skenario 8 & 613 & 554 & 193 & 137 \\
Skenario 9 & 558 & 558 & 61 & 57 \\
Skenario 10 & 1150 & 1089 & 61 & 57 \\
Skenario 11 & 465 & 465 & 61 & 57 \\
Skenario 12 & 1150 & 1089 & 61 & 57 \\
Skenario 13 & 420 & 420 & 61 & 57 \\
Skenario 14 & 1150 & 1089 & 61 & 57 \\
Skenario 15 & 395 & 395 & 61 & 57 \\
Skenario 16 & 1150 & 1089 & 61 & 57 \\
Skenario 17 & 588 & 588 & 61 & 57 \\
Skenario 18 & 1150 & 1089 & 61 & 57 \\
Skenario 19 & 465 & 465 & 61 & 57 \\
Skenario 20 & 1150 & 1089 & 61 & 57 \\
Skenario 21 & 420 & 420 & 61 & 57 \\
Skenario 22 & 1150 & 1089 & 61 & 57 \\
Skenario 23 & 395 & 395 & 61 & 57 \\
Skenario 24 & 1150 & 1089 & 61 & 57 \\
\hline
\end{tabular}

Tabel 10. Akurasi algoritma C4.5 dan CART untuk semua skenario

\begin{tabular}{|c|c|c|c|c|c|c|}
\hline \multirow[b]{2}{*}{$\begin{array}{c}\text { Nama } \\
\text { Skenario }\end{array}$} & \multirow[b]{2}{*}{$\begin{array}{c}\text { Atrr } \\
\text { Numerik }\end{array}$} & \multicolumn{2}{|c|}{ Akurasi (\%) } & \multicolumn{2}{|c|}{ Data Latih } & \multirow[b]{2}{*}{$\begin{array}{l}\text { Kate } \\
\text { gori IP }\end{array}$} \\
\hline & & C4.5 & CART & $\begin{array}{l}\text { Seim } \\
\text { bang }\end{array}$ & $\begin{array}{c}\text { Tidak } \\
\text { Seimbang }\end{array}$ & \\
\hline$\overline{\text { Skenario } 1}$ & - & 57,66 & 57,66 & $\mathrm{~V}$ & & 2 \\
\hline Skenario 2 & - & 86,86 & 86,86 & & V & 2 \\
\hline Skenario 3 & - & 40,15 & 37,23 & V & & 3 \\
\hline Skenario 4 & - & 63,50 & 62,77 & & $\mathrm{~V}$ & 3 \\
\hline Skenario 5 & - & 43,07 & 40,88 & V & & 4 \\
\hline Skenario 6 & - & 66,42 & 68,61 & & V & 4 \\
\hline Skenario 7 & - & 20,44 & 18,98 & V & & 5 \\
\hline Skenario 8 & - & 51,82 & 52,55 & & V & 5 \\
\hline Skenario 9 & Threshold & 45,61 & 56,14 & V & & 2 \\
\hline Skenario 10 & Threshold & 52,63 & 63,16 & & V & 2 \\
\hline Skenario 11 & Threshold & 33,33 & 26,32 & V & & 3 \\
\hline Skenario 12 & Threshold & 40,35 & 49,12 & & V & 3 \\
\hline Skenario 13 & Threshold & 31,58 & 31,58 & V & & 4 \\
\hline Skenario 14 & Threshold & 24,56 & 28,07 & & V & 4 \\
\hline Skenario 15 & Threshold & 22,81 & 26,32 & V & & 5 \\
\hline Skenario 16 & Threshold & 28,07 & 36,60 & & V & 5 \\
\hline Skenario 17 & Binning & 57,41 & 56,14 & V & & 2 \\
\hline Skenario 18 & Binning & 61,54 & 57,89 & & V & 2 \\
\hline Skenario 19 & Binning & 31,37 & 29,82 & V & & 3 \\
\hline Skenario 20 & Binning & 28,30 & 42,11 & & V & 3 \\
\hline Skenario 21 & Binning & 26,42 & 24,56 & V & & 4 \\
\hline Skenario 22 & Binning & 35,29 & 22,81 & & V & 4 \\
\hline Skenario 23 & Binning & 18,87 & 14,04 & V & & 5 \\
\hline Skenario 24 & Binning & 27,45 & 33,33 & & V & 5 \\
\hline & Rata-rata & 41,48 & 42,65 & & & \\
\hline
\end{tabular}

Rangkuman hasil pengujian untuk kasus penerimaan mahasiswa melalui jalur prestasi dan non-prestasi dengan kategori indeks prestasi sebanyak 2 kategori dinyatakan dalam Tabel 13. Akurasi rata-rata untuk algoritma C4.5 adalah 60,29\% dan algoritma CART adalah $62,98 \%$. 
Tabel 11. Akurasi algoritma C4.5 dan CART pada kasus penerimaan mahasiswa jalur prestasi

\begin{tabular}{cccccc}
\hline Nama & \multicolumn{2}{c}{ Data Latih } & \multicolumn{2}{c}{ Akurasi (\%) } & Kategori \\
\cline { 2 - 4 } Skenario & Seimbang & $\begin{array}{c}\text { Tidak } \\
\text { Seimbang }\end{array}$ & C4.5 & CART & IP \\
\hline Skenario 1 & V & & 57,66 & 57,66 & 2 \\
Skenario 2 & & V & 86,86 & 86,86 & 2 \\
Skenario 3 & V & & 40,15 & 37,23 & 3 \\
Skenario 4 & & V & 66,42 & 68,61 & 3 \\
Skenario 5 & V & & 43,07 & 40,88 & 4 \\
Skenario 6 & & V & 63,50 & 62,77 & 4 \\
Skenario 7 & V & & 20,44 & 18,98 & 5 \\
Skenario 8 & & V & 51,82 & 52,55 & 5 \\
& & Rata-rata & $\mathbf{5 2 , 8 4}$ & $\mathbf{5 3 , 5 2}$ & \\
\hline
\end{tabular}

Tabel 12. Akurasi algoritma C4.5 dan CART pada kasus penerimaan mahasiswa jalur non-prestasi.

\begin{tabular}{|c|c|c|c|c|c|}
\hline \multirow{2}{*}{$\begin{array}{c}\text { Nama } \\
\text { Skenario }\end{array}$} & \multicolumn{2}{|c|}{ Data Latih } & \multicolumn{2}{|c|}{ Akurasi (\%) } & \multirow{2}{*}{$\begin{array}{c}\text { Kategori } \\
\text { IP }\end{array}$} \\
\hline & Seimbang & $\begin{array}{c}\text { Tidak } \\
\text { Seimbang }\end{array}$ & $\mathrm{C} 4.5$ & CART & \\
\hline Skenario 9 & $\mathrm{~V}$ & & 45,61 & 56,14 & 2 \\
\hline Skenario 10 & & V & 52,63 & 63,16 & 2 \\
\hline Skenario 11 & V & & 33,33 & 26,32 & 3 \\
\hline Skenario 12 & & $\mathrm{~V}$ & 40,35 & 49,12 & 3 \\
\hline Skenario 13 & V & & 31,58 & 31,58 & 4 \\
\hline Skenario 14 & & V & 24,56 & 28,07 & 4 \\
\hline Skenario 15 & V & & 22,81 & 26,32 & 5 \\
\hline Skenario 16 & & V & 28,07 & 36,60 & 5 \\
\hline Skenario 17 & V & & 57,41 & 56,14 & 2 \\
\hline Skenario 18 & & V & 61,54 & 57,89 & 2 \\
\hline Skenario 19 & V & & 31,37 & 29,82 & 3 \\
\hline Skenario 20 & & V & 28,30 & 42,11 & 3 \\
\hline Skenario 21 & V & & 26,42 & 24,56 & 4 \\
\hline Skenario 22 & & V & 35,29 & 22,81 & 4 \\
\hline Skenario 23 & V & & 18,87 & 14,04 & 5 \\
\hline \multirow[t]{2}{*}{ Skenario 24} & & V & 27,45 & 33,33 & 5 \\
\hline & & Rata-rata & 35,35 & 37,38 & \\
\hline
\end{tabular}

Tabel 13. Akurasi algoritma C4.5 dan CART dengan kategori indeks prestasi sebanyak 2 kategori

\begin{tabular}{|c|c|c|c|c|c|}
\hline \multirow{2}{*}{$\begin{array}{c}\text { Nama } \\
\text { Skenario }\end{array}$} & \multirow{2}{*}{ Jalur Penerimaan } & \multirow{2}{*}{$\begin{array}{c}\text { Atribut } \\
\text { Numerik }\end{array}$} & \multicolumn{2}{|c|}{ Akurasi (\%) } & \multirow{2}{*}{$\begin{array}{c}\text { Data } \\
\text { Latih } \\
\text { Seimbang }\end{array}$} \\
\hline & & & C4.5 & CART & \\
\hline & J & - & 5 & 57, & $\mathrm{~V}$ \\
\hline $\mathrm{Sk}$ & Jalu & - & 6 & & $\mathrm{X}$ \\
\hline Skenario 9 & Jalur Non-Prestasi & Thresh & 45,61 & 56 & V \\
\hline Skenario 10 & Jalur Non-Prestasi & Threshold & 52,63 & 63,16 & $\mathrm{X}$ \\
\hline Skenario 17 & 7 Jalur Non-Prestasi & Binning & 57,41 & 56,14 & V \\
\hline \multirow{2}{*}{\multicolumn{2}{|c|}{ Skenario 18 Jalur Non-Prestasi }} & Binning & 61,54 & 57,89 & $\mathrm{X}$ \\
\hline & & Rata-rata & 60,29 & 62,98 & \\
\hline
\end{tabular}

Rangkuman hasil pengujian untuk kasus penerimaan mahasiswa melalui jalur prestasi dan non-prestasi dengan indeks prestasi sebanyak 3 kategori dinyatakan dalam Tabel 14. Akurasi rata-rata untuk algoritma C4.5 adalah 39,99\% dan algoritma CART adalah 42,20\%.

Rangkuman hasil pengujian untuk kasus penerimaan mahasiswa melalui jalur prestasi dan non-prestasi dengan indeks prestasi sebanyak 4 kategori dinyatakan dalam Tabel 15. Akurasi rata-rata untuk algoritma C4.5 adalah 37,40\% dan algoritma CART adalah 35,11\%.

Rangkuman hasil pengujian untuk kasus penerimaan mahasiswa melalui jalur prestasi dan non-prestasi dengan indeks prestasi sebanyak 5 kategori dinyatakan dalam Tabel 16. Akurasi rata-rata untuk algoritma C4.5 adalah 28,24\% dan algoritma CART adalah 30,30\%.
Tabel 14. Akurasi algoritma C4.5 dan CART dengan kategori indeks prestasi sebanyak 3 kategori

\begin{tabular}{|c|c|c|c|c|c|}
\hline \multirow{2}{*}{$\begin{array}{c}\text { Nama } \\
\text { Skenario }\end{array}$} & \multirow[b]{2}{*}{ Jalur Penerimaan } & \multirow{2}{*}{$\begin{array}{c}\text { Atribut } \\
\text { Numerik }\end{array}$} & \multicolumn{2}{|c|}{ Akurasi (\%) } & \multirow{2}{*}{$\begin{array}{c}\text { Data } \\
\text { Latih } \\
\text { Seimbang }\end{array}$} \\
\hline & & & C4.5 & CART & \\
\hline Skenario 3 & Jalur Prestasi & - & 40,15 & 37,23 & $\mathrm{~V}$ \\
\hline Skenario 4 & Jalur Prestasi & - & 66,42 & 68,61 & $\mathrm{X}$ \\
\hline Skenario 11 & Jalur Non-Prestasi & Threshold & 33,33 & 26,32 & V \\
\hline Skenario 12 & Jalur Non-Prestasi & Threshold & 40,35 & 49,12 & $\mathrm{X}$ \\
\hline Skenario 19 & Jalur Non-Prestasi & Binning & 31,37 & 29,82 & V \\
\hline \multirow{2}{*}{\multicolumn{2}{|c|}{ Skenario 20 Jalur Non-Prestasi }} & Binning & 28,30 & 42,11 & $\mathrm{X}$ \\
\hline & & Rata-rata & 39,99 & 42,20 & \\
\hline
\end{tabular}

Tabel 15. Akurasi algoritma C4.5 dan CART dengan kategori indeks prestasi sebanyak 4 kategori

\begin{tabular}{|c|c|c|c|c|c|}
\hline \multirow{2}{*}{$\begin{array}{c}\text { Nama } \\
\text { Skenario }\end{array}$} & \multirow{2}{*}{ Jalur Penerimaan } & \multirow{2}{*}{$\begin{array}{c}\text { Atribut } \\
\text { Numerik }\end{array}$} & \multicolumn{2}{|c|}{ Akurasi (\%) } & \multirow{2}{*}{$\begin{array}{c}\text { Data } \\
\text { Latih } \\
\text { Seimbang }\end{array}$} \\
\hline & & & $\mathrm{C} 4.5$ & CART & \\
\hline Skenario 5 & Jalur Prestasi & - & 43,07 & 40,88 & $\mathrm{~V}$ \\
\hline Skenario 6 & Jalur Prestasi & - & 63,50 & 62,77 & $\mathrm{X}$ \\
\hline Skenario 13 & Jalur Non-Prestasi & Threshold & 31,58 & 31,58 & V \\
\hline Skenario 14 & Jalur Non-Prestasi & Threshold & 24,56 & 28,07 & $\mathrm{X}$ \\
\hline Skenario 21 & Jalur Non-Prestasi & Binning & 26,42 & 24,56 & V \\
\hline \multirow{2}{*}{\multicolumn{2}{|c|}{ Skenario 22 Jalur Non-Prestasi }} & Binning & 35,29 & 22,81 & $\mathrm{X}$ \\
\hline & & Rata-rata & 37,40 & 35,11 & \\
\hline
\end{tabular}

Tabel 16. Akurasi algoritma C4.5 dan CART dengan kategori indeks prestasi sebanyak 5 kategori

\begin{tabular}{|c|c|c|c|c|c|}
\hline \multirow{2}{*}{$\begin{array}{c}\text { Nama } \\
\text { Skenario }\end{array}$} & \multirow[t]{2}{*}{ Jalur Penerimaan } & \multirow{2}{*}{$\begin{array}{c}\text { Atribut } \\
\text { Numerik }\end{array}$} & \multicolumn{2}{|c|}{ Akurasi (\%) } & \multirow{2}{*}{$\begin{array}{c}\text { Data } \\
\text { Latih } \\
\text { Seimbang }\end{array}$} \\
\hline & & & C4.5 & CART & \\
\hline Skenario 7 & Jalur Pres & - & 20,44 & 18,98 & $\mathrm{~V}$ \\
\hline Skenario 8 & Jalur Prestasi & - & 51,82 & 52,55 & $\mathrm{X}$ \\
\hline Skenario 15 & 5 Jalur Non-Prestasi & Threshold & 22,81 & 26,32 & V \\
\hline Skenario 16 & 6 Jalur Non-Prestasi & Threshold & 28,07 & 36,60 & $\mathrm{X}$ \\
\hline Skenario 23 & 3 Jalur Non-Prestasi & Binning & 18,87 & 14,04 & V \\
\hline \multirow{2}{*}{\multicolumn{2}{|c|}{ Skenario 24 Jalur Non-Prestasi }} & Binning & 27,45 & 33,33 & $\mathrm{X}$ \\
\hline & & Rata-rata & 28,24 & $\mathbf{3 0 , 3 0}$ & \\
\hline
\end{tabular}

Tabel 17. Akurasi algoritma C4.5 dan CART pada kasus penerimaan mahasiswa jalur non-prestasi dengan atribut numerik di-threshold

\begin{tabular}{|c|c|c|c|c|c|}
\hline \multirow{2}{*}{$\begin{array}{c}\text { Nama } \\
\text { Skenario }\end{array}$} & \multicolumn{2}{|c|}{ Akurasi (\%) } & \multirow[t]{2}{*}{ Seimbang } & \multirow{2}{*}{$\begin{array}{c}\text { Tidak } \\
\text { Seimbang }\end{array}$} & \multirow{2}{*}{$\begin{array}{c}\text { Kategori } \\
\text { IP }\end{array}$} \\
\hline & C4.5 & CART & & & \\
\hline Skenario 9 & 45,61 & 56,14 & $\mathrm{~V}$ & & 2 \\
\hline Skenario 10 & 52,63 & 63,16 & & V & 2 \\
\hline Skenario 11 & 33,33 & 26,32 & V & & 3 \\
\hline Skenario 12 & 40,35 & 49,12 & & V & 3 \\
\hline Skenario 13 & 31,58 & 31,58 & V & & 4 \\
\hline Skenario 14 & 24,56 & 28,07 & & V & 4 \\
\hline Skenario 15 & 22,81 & 26,32 & V & & 5 \\
\hline Skenario 16 & 28,07 & 36,60 & & V & 5 \\
\hline Rata-rata & 34,87 & 39,66 & & & \\
\hline
\end{tabular}

Rangkuman hasil pengujian untuk kasus penerimaan mahasiswa melalui jalur non-prestasi dengan atribut numerik di-threshold dinyatakan dalam Tabel 17. Akurasi rata-rata untuk algoritma $\mathrm{C} 4.5$ adalah 37,37\% dan algoritma CART adalah 41,00\%. Rangkuman hasil pengujian untuk kasus penerimaan mahasiswa melalui jalur non-prestasi dengan atribut numerik di-binning dinyatakan dalam Tabel 18. Akurasi rata-rata untuk algoritma C4.5 adalah 35,83\% dan algoritma CART sebesar $35,09 \%$. 
Tabel 18. Akurasi algoritma C4.5 dan CART pada kasus penerimaan mahasiswa jalur non-prestasi dengan atribut numerik di-binning

\begin{tabular}{cccccc}
\hline Nama & \multicolumn{2}{c}{ Akurasi (\%) } & \multirow{2}{*}{ Seimbang } & $\begin{array}{c}\text { Tidak } \\
\text { Seimbang }\end{array}$ & $\begin{array}{c}\text { Kategori } \\
\text { IP }\end{array}$ \\
\cline { 2 - 3 } Skenario & $\mathbf{C 4 . 5}$ & CART & & & 2 \\
\hline Skenario 17 & 57,41 & 56,14 & $\mathrm{~V}$ & & 2 \\
Skenario 18 & 61,54 & 57,89 & & $\mathrm{~V}$ & 3 \\
Skenario 19 & 31,37 & 29,82 & $\mathrm{~V}$ & & 3 \\
Skenario 20 & 28,30 & 42,11 & & $\mathrm{~V}$ & 4 \\
Skenario 21 & 26,42 & 24,56 & $\mathrm{~V}$ & & 4 \\
Skenario 22 & 35,29 & 22,81 & & $\mathrm{~V}$ & 5 \\
Skenario 23 & 18,87 & 14,04 & $\mathrm{~V}$ & & 5 \\
Skenario 24 & 27,45 & 33,33 & & $\mathrm{~V}$ & 5 \\
Rata-rata & $\mathbf{3 5 , 8 3}$ & $\mathbf{3 5 , 0 9}$ & & & \\
\hline
\end{tabular}

Tabel 19. Akurasi algoritma C4.5 dan CART dengan data latih yang seimbang

\begin{tabular}{cccccc}
\hline Nama & Jalur & Atribut & \multicolumn{2}{c}{ Akurasi (\%) } & \multirow{2}{*}{ Kategori IP } \\
\cline { 5 - 6 } Skenario & Penerimaan & Numerik & C4.5 & CART & \\
\hline Skenario 1 & Japres & - & 57,66 & 57,66 & 2 \\
Skenario 3 & Japres & - & 40,15 & 37,23 & 3 \\
Skenario 5 & Japres & - & 43,07 & 40,88 & 4 \\
Skenario 7 & Japres & - & 20,44 & 18,98 & 5 \\
Skenario 9 & Non-Japres & Threshold & 45,61 & 56,14 & 2 \\
Skenario 11 & Non-Japres & Threshold & 33,33 & 26,32 & 3 \\
Skenario 13 & Non-Japres & Threshold & 31,58 & 31,58 & 4 \\
Skenario 15 & Non-Japres & Threshold & 22,81 & 26,32 & 5 \\
Skenario 17 & Non-Japres & Binning & 57,41 & 56,14 & 2 \\
Skenario 19 & Non-Japres & Binning & 31,37 & 29,82 & 3 \\
Skenario 21 & Non-Japres & Binning & 26,42 & 24,56 & 4 \\
Skenario 23 & Non-Japres & Binning & 18,87 & 14,04 & 5 \\
& & Rata-rata & $\mathbf{3 5 , 7 3}$ & $\mathbf{3 4 , 9 7}$ & \\
\hline
\end{tabular}

Tabel 20. Akurasi algoritma C4.5 dan CART dengan data latih yang tidak seimbang.

\begin{tabular}{cccccc}
\hline Nama & \multirow{2}{*}{$\begin{array}{c}\text { Jalur Penerimaan } \\
\text { Skenario }\end{array}$} & \multirow{2}{*}{$\begin{array}{c}\text { Atribut } \\
\text { Numerik }\end{array}$} & \multicolumn{2}{c}{ Akurasi (\%) } & Kategori \\
\cline { 4 - 5 } & & - & 86,86 & 86,86 & 2 \\
Skenario 2 & Japres & - & 66,42 & 68,61 & 3 \\
Skenario 4 & Japres & - & 63,50 & 62,77 & 4 \\
Skenario 6 & Japres & - & 51,82 & 52,55 & 5 \\
Skenario 8 & Japres & IP & \\
Skenario 10 & Non-Japres & Threshold & 52,63 & 63,16 & 2 \\
Skenario 12 & Non-Japres & Threshold & 40,35 & 49,12 & 3 \\
Skenario 14 & Non-Japres & Threshold & 24,56 & 28,07 & 4 \\
Skenario 16 & Non-Japres & Threshold & 28,07 & 36,60 & 5 \\
Skenario 18 & Non-Japres & Binning & 61,54 & 57,89 & 2 \\
Skenario 20 & Non-Japres & Binning & 28,30 & 42,11 & 3 \\
Skenario 22 & Non-Japres & Binning & 35,29 & 22,81 & 4 \\
Skenario 24 & Non-Japres & Binning & 27,45 & 33,33 & 5 \\
& & Rata-rata & $\mathbf{4 7 , 2 3}$ & $\mathbf{5 0 , 3 2}$ & \\
\hline
\end{tabular}

Rangkuman hasil pengujian dengan data latih yang seimbang dinyatakan dalam Tabel 19. Akurasi rata-rata untuk algoritma $\mathrm{C} 4.5$ adalah $35,73 \%$ dan algoritma CART adalah $34,97 \%$. Rangkuman hasil pengujian dengan data latih yang tidak seimbang dinyatakan dalam Tabel 20. Akurasi rata-rata untuk algoritma C4.5 adalah $47,23 \%$ dan algoritma CART adalah 50,32\%.

Berdasarkan kategorisasi atribut numerik untuk data jalur non-prestasi, algoritma C4.5 dengan atribut numerik di-binning memiliki akurasi rata-rata yang lebih baik, yaitu sebesar 35,83\%, dibandingkan dengan atribut numerik yang di-threshold, yaitu sebesar $34,87 \%$. Algoritma CART dengan atribut numerik dithreshold memiliki akurasi rata-rata yang lebih baik, yaitu sebesar 39,66\% dibandingkan dengan atribut

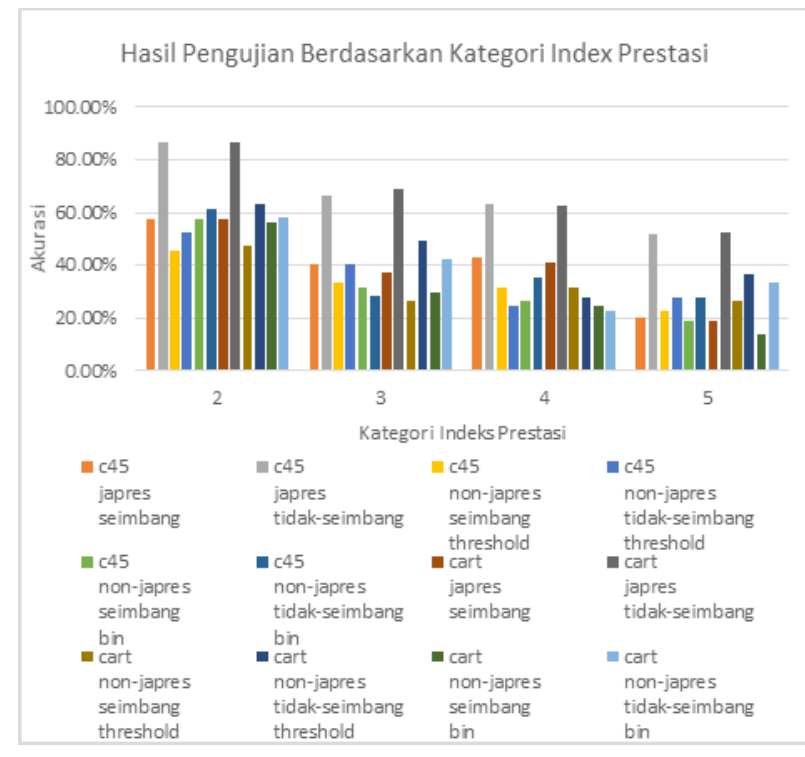

Gambar 2. Hasil pengujian berdasarkan kategori indeks prestasi

numerik yang di-binning, yaitu sebesar 35,09\%. Berdasarkan keseimbangan data, data yang tidak seimbang memiliki akurasi rata-rata yang baik, yaitu C4.5 memiliki akurasi rata-rata sebesar $47,23 \%$ dan CART memiliki akurasi rata-rata sebesar 50,32\%, dibandingkan dengan data yang seimbang.

Secara keseluruhan, akurasi rata-rata algoritma CART lebih tinggi daripada akurasi rata-rata algoritma C4.5. Akurasi rata-rata algoritma CART sebesar $42,65 \%$ sedangkan akurasi rata-rata algoritma C4.5 sebesar 41,48\%. Akurasi rata-rata kedua algoritma tersebut sangat dipengaruhi oleh faktor-faktor seperti jumlah kategori indeks prestasi, keseimbangan data, kategorisasi (binning) untuk atribut numerik, dan kualitas data itu sendiri.

Perbandingan akurasi algoritma terhadap jumlah_kategori_ip ditunjukkan dalam Gambar 2 . Semakin banyak kategori IP, semakin kecil akurasi algoritma. Grafik tersebut juga menunjukkan bahwa prediksi jalur prestasi (japres) data tidak seimbang dithreshold menunjukkan nilai akurasi lebih tinggi dibandingkan dengan data lain.

Gambar 3 menunjukkan perbandingan hasil pengujian berdasarkan jalur penerimaan mahasiswa, yaitu jalur prestasi (japres) dan jalur non-prestasi (nonjapres) yang di-threshold. Pada beberapa skenario, data japres menghasilkan akurasi yang jauh lebih tinggi daripada data non-japres dengan atribut lain yang sama, terutama pada jumlah kategori indeks prestasi yang kecil. Pada beberapa skenario lainnya, data japres menghasilkan akurasi yang tidak jauh lebih tinggi dari data non-japres dan bahkan pada beberapa skenario data non-japres menghasilkan akurasi lebih tinggi daripada data japres. Ada kesamaan pola perbandingan akurasi data japres dan data non-japres pada metode C4.5 dan CART. Hanya pada skenario kategori indeks prestasi 5 dengan data seimbang, akurasi C4.5 untuk data japres lebih tinggi daripada data non-japres, sedangkan akurasi 


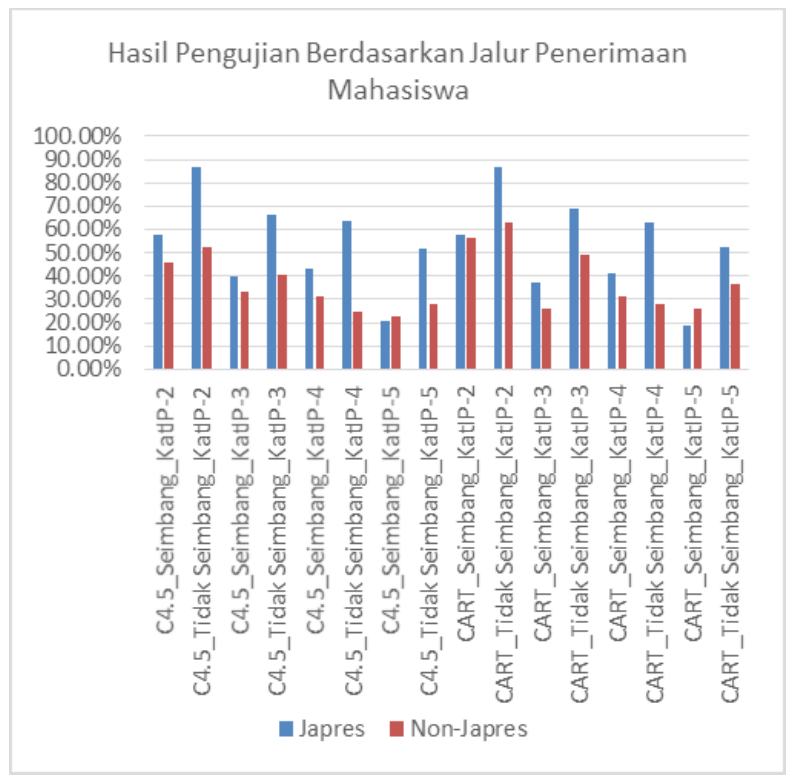

Gambar 3. Hasil pengujian berdasarkan jalur penerimaan mahasiswa

CART untuk data japres lebih rendah daripada data nonjapres.

Gambar 4 menunjukkan perbandingan hasil pengujian berdasarkan pengkategorian atribut numerik pada kasus penerimaan mahasiswa pada jalur nonprestasi, yaitu atribut numerik yang di-binning dan atribut numerik yang di-threshold. Dari grafik tersebut dapat dilihat bahwa tidak ada pola dampak binning terhadap akurasi. Binning meningkatkan akurasi secara signifikan pada saat jumlah kategori indeks prestasi 2, menurunkan akurasi secara signifikan pada saat jumlah kategori indeks prestasi 3 dan 4, dan tidak berdampak secara signifikan pada saat jumlah kategori indeks prestasi 5. Pola tersebut terlihat pada algoritma C4.5 dan CART.

Gambar 5 menunjukkan grafik perbandingan hasil pengujian berdasarkan keseimbangan data, yaitu data latih yang seimbang dan data latih yang tidak seimbang. Dari grafik tersebut dapat dilihat bahwa 20 dari 24 pasang skenario dengan parameter yang sama diprediksi menggunakan data latih yang sudah diseimbangkan memiliki akurasi yang lebih rendah dibandingkan dengan prediksi menggunakan data latih yang tidak diseimbangkan. Sebanyak 6 dari 20 pasang skenario tersebut memiliki selisih akurasi lebih dari $20 \%$. Sebanyak 4 dari 24 pasang skenario diprediksi menggunakan data latih yang diseimbangkan memiliki akurasi yang sedikit lebih tinggi dibandingkan dengan menggunakan data latih yang tidak diseimbangkan.

Dari hasil penelitian ini, didapatkan bahwa akurasi terbaik algoritma C4.5 dan CART pada data jalur prestasi lebih tinggi dari data jalur non-prestasi. Pada data jalur prestasi, akurasi terbaik kedua algoritma tersebut mencapai $86,86 \%$, sedangkan pada data jalur non-prestasi, akurasi terbaik algoritma $\mathrm{C} 4.5$ adalah 61,54\% dan CART adalah 63,16\%.

Dari hasil pengujian kedua algoritma tersebut dapat dinyatakan bahwa akurasi terbaik algoritma CART pada

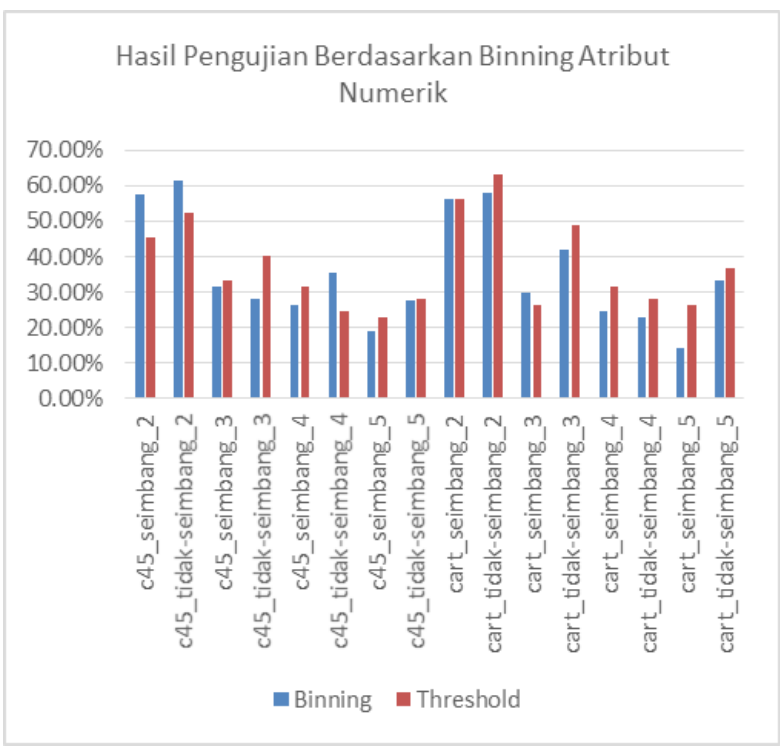

Gambar 4. Grafik hasil pengujian berdasarkan binning atribut numerik

Hasil Pengujian Berdasarkan Keseimbangan Data

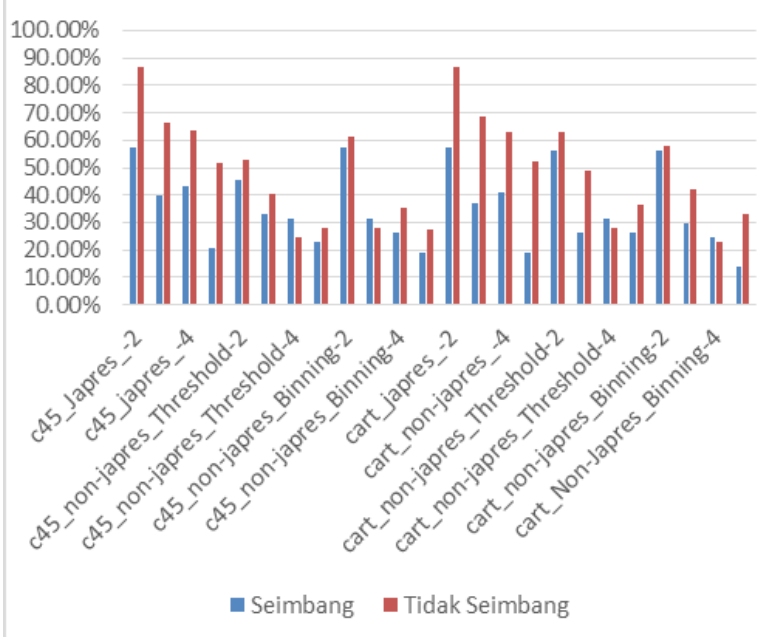

Gambar 5. Grafik hasil pengujian berdasarkan keseimbangan data

data jalur non-prestasi (data numerik) adalah 63,16\%. Jika dibandingkan dengan [8] yang menyatakan bahwa algoritma CART cocok digunakan untuk data numerik daripada algoritma C4.5, maka dapat dinyatakan juga bahwa algoritma CART memberikan akurasi yang lebih baik daripada algoritma $\mathrm{C} 4.5$ pada data numerik.

Ketika data yang digunakan adalah data jalur prestasi (data non-numerik), dapat dinyatakan bahwa algoritma C4.5 dan CART memiliki akurasi yang sama, yaitu $86,86 \%$. Jika dibandingkan dengan [8] yang menyatakan bahwa algoritma C4.5 memberikan akurasi yang lebih baik daripada algoritma CART pada data non-numerik dan [9] yang menyatakan bahwa akurasi algoritma CART lebih baik daripada algoritma C4.5 pada data non-numerik, maka dapat dinyatakan bahwa hal tersebut bertentangan dengan hasil penelitian yang 
Tabel 21. Perbandingan akurasi algoritma C4.5, CART, regresi logistik, K-Nearest Neighbor, dan Näive Bayes Classifier.

\begin{tabular}{lcc}
\hline \multirow{2}{*}{ Algoritma/Metode } & \multicolumn{2}{c}{ Jalur Penerimaan } \\
\cline { 2 - 3 } & $\begin{array}{c}\text { Jalur } \\
\text { Prestasi }\end{array}$ & $\begin{array}{c}\text { Jalur Non- } \\
\text { Prestasi }\end{array}$ \\
\hline C4.5 & $86.86 \%$ & $61.54 \%$ \\
CART & $86.86 \%$ & $63.16 \%$ \\
Regresi Logistik [1], [5] & $72.00 \%$ & $60.70 \%$ \\
K-Nearest Neighbor [6] & $61.00 \%$ & $52.00 \%$ \\
Naïve Bayes Classifier [6] & $55.00 \%$ & $41.00 \%$ \\
\hline
\end{tabular}

menyatakan bahwa algoritma C4.5 dan CART memiliki akurasi yang sama pada data non-numerik.

Perbandingan algoritma C4.5 dan CART dengan algoritma lain ditunjukkan dalam Tabel 21, yaitu regresi logistik untuk jalur prestasi [1] dan non-prestasi [5] serta metode K-Nearest Neighbor $(\mathrm{k}=2)$ dan Naive Bayes Classifier [6]. Algoritma yang paling baik untuk memprediksi kategori indeks prestasi mahasiswa untuk jalur prestasi adalah algoritma C4.5 dan CART dengan akurasi sebesar $86,86 \%$ dan algoritma yang paling baik untuk memprediksi kategori indeks prestasi mahasiswa untuk jalur non-prestasi adalah algoritma CART dengan akurasi sebesar 63,16\%. Metode K-Nearest Neighbor menggunakan nilai $\mathrm{k}=5$ dan $\mathrm{k}=7$. Rasio data uji dan data latih yang digunakan menentukan akurasi prediksi, seperti jika dibandingkan dengan akurasi terbaik 92,79\% dalam Untari [3] yang menggunakan C4.5 dan rasio data latih berbeda-beda (10\%-90\%) dan dengan akurasi $80,87 \%$ dalam Aprilia dkk. [7] yang menggunakan CART dan rasio data latih $84 \%$. Penelitian ini menggunakan rasio data latih tetap, yaitu sebesar $76,05 \%$ dan akurasi terbaik diukur menggunakan data tidak seimbang.

Permasalahan pada penelitian ini adalah adanya missing value pada saat pengujian yang diatasi dengan cara discard. Penggunaan cara lain untuk mengatasi missing value dapat dilakukan dengan imputation, $\mathrm{C} 4.5$ strategy, null strategy, dan lazy decision tree seperti yang disajikan dalam [11]. Prediksi indeks prestasi (IP) mahasiswa semester satu yang dilakukan secara dini ini dapat digunakan untuk menanggulangi masalah-masalah yang mungkin akan dialami oleh mahasiswa di kemudian hari. Fakultas bisa melacak mahasiswamahasiswa yang berpotensi memiliki IP semester satu yang rendah untuk dilakukan pembimbingan lebih lanjut terhadap mahasiswa tersebut. Selain itu, prediksi juga bisa dimanfaatkan untuk melakukan penyaringan calon mahasiswa baru.

\section{KESIMPULAN}

Algoritma C4.5 dan CART memiliki akurasi yang sama untuk memprediksi kategori IP mahasiswa baru pada jalur prestasi (data non-numerik), yaitu sebesar $86,86 \%$. Untuk memprediksi kategori IP mahasiswa baru pada jalur non-prestasi (data numerik), algoritma CART memberikan akurasi lebih baik daripada C4.5, yaitu $63,16 \%$ berbanding $61,54 \%$.

\section{Daftar Pustaka}

[1] R. G. Santosa and A. R. Chrismanto, "Logistic Regression Model for Predicting First Semester Students Gpa Category Based on High School Academic Achievement," Journal of Arts, Science \& Commerce, vol. VIII, no. 2(1), pp. 58-66, April 2017.

[2] D. Indriana, A. I. Widowati, and S. Surjawati,"Faktor-Faktor yang Mempengaruhi Prestasi Akademik: Studi Kasus pada Mahasiswa Program Studi Akuntansi Universitas Semarang," Jurnal Dinamika Sosial Budaya, vol. 18, no. 1, pp. 39-48, Juni 2016.

[3] D. Untari, "Data Mining Untuk Menganalisa Prediksi Mahasiswa Berpotensi Non-Aktif Menggunakan Metode Decision Tree C4.5," Skripsi, Universitas Dian Nuswantoro, Semarang, 2014 [Online]. Available: http://eprints.dinus.ac.id/ $13181 /$

[4] D. H. Kamagi and S. Hansun, "Implementasi Data Mining dengan Algoritma C4.5 untuk Memprediksi Tingkat Kelulusan Mahasiswa," Ultimatics, vol. VI, no. 1, pp. 15-20, Juni 2014.

[5] R. G. Santosa and A. R. Chrismanto, "Perbandingan Akurasi Model Regresi Logistik Untuk Prediksi Kategori IP Mahasiswa Jalur Prestasi dengan Non Jalur Prestasi," Jurnal Teknik dan Ilmu Komputer, vol. 7, no. 25, pp. 107-121, Januari 2018.

[6] V. H. A. Sari, R. G. Santosa, and A. Rachmat, "Perbandingan Algoritma K-Nearest Neighbor dan Naïve Bayes Classifier dalam Memprediksi Kategori Indeks Prestasi Mahasiswa," Laporan tidak dipublikasi, 2017.

[7] T. Aprilia, N. Gusriani, and K. Parmikanti, "Klasifikasi Ketepatan Masa Studi Mahasiswa FMIPA Unpad Angkatan 2001-2006 dengna Menggunakan Metode Classification and Regression Trees (CART)," Jurnal Matematika Integratif, vol. 11, no. 1, pp. 7-14, April 2015

[8] I. Rahmayuni, "Perbandingan Performansi Algoritma C4.5 dan CART Dalam Klasifikasi Data Nilai Mahasiswa Prodi Teknik Komputer Politeknik Negeri Padang," Jurnal TEKNOIF, vol. 2, no. 1, pp. 40-46, April 2014.

[9] T. M. Lakshmi, A. Martin, R. M. Begum, and V. P. Venkatesan, "An Analysis on Performance of Decision Tree Algorithms using Student's Qualitative Data," International Journal of Modern Education and Computer Science, vol. 5, no. 5, pp. 18-27, 2013.

[10] C. Brooks, Entreprise NoSQL For Dummies. John Wiley \& Sons, Inc, 2014.

[11] S. Gavankar and S. Sawarkar, "Decision Tree: Review of Techniques for Missing Values at Training, Testing and Compatibility," in Proc. of 3rd International Conference on Artificial Intelligence, Modelling and Simulation (AIMS 2015), Malaysia, Dec. 2-4, 2015, pp. 122-126. 